\section{C-1027 Enediyne Chromophore: Presence of Another Active Form and Its Chemical Structure}

\author{
Toshio Otani* ${ }^{*}$, Ken-IChIro Yoshida, Toru Sasaki \\ and YoSHINORI MINAMI \\ Tokushima Research Center, \\ Taiho Pharmaceutical Co. Ltd., \\ Kawauchi-cho, Tokushima 771-0132, Japan
}

(Received for publication December 24, 1998)

Antibiotic C-1027, a member of a family of potent antitumor chromoproteins, was isolated from the culture supernatant of Streptomyces globisporus C-1027 ${ }^{1}$, and found to display antimicrobial activity as well as to have potent cytotoxic effects ${ }^{2}$. C-1027 was shown to consist of two components, an acidic protein of 110 amino acid residues, previously sequenced ${ }^{3,4)}$, and a non-protein chromophore extractable with organic solvents, which was very labile in the free form as is the case for chromophores of known chromoproteins such as neocarzinostatin (NCS), auromomycin, actinoxanthin, kedarcidin, and maduropeptin ${ }^{5,6)}$. By a detailed analyses of the ${ }^{1} \mathrm{H}$ and ${ }^{13} \mathrm{C}$ NMR spectra with the aid of 2D-NMR technique of aromatized C-1027 chromophore III (ChrIII), the native C-1027 chromophore IV (Chr-IV) was shown to possess a 9-membered 1,5 diyn-3-ene core structure in a 16-membered macrocyclic ring together with benzoxazolinate and aminosugar moieties as side chains $^{7 \sim 9)}$ (Fig. 1). The biological activity of the chromophore has been attributed to its ability to produce DNA damage following rearrangement to form a diradical species which abstracts hydrogen atoms from deoxyribose even in the absence of reducing agent ${ }^{10 \sim 12)}$, in contrast to other enediyne antibiotics that required a reducing agent. It also has been shown that the apoproteins of chromoprotein antibiotics, as seen with C-1027, show a high degree of amino acid sequence homology, stabilize the chromophores ${ }^{1)}$ and additionally function as a targeting vehicle for the chromophore ${ }^{13}$.

Recently, for further toxicological evaluation and formulation studies, we have attempted to improve the purification procedure to make it more suitable for large-scale operations. In the present work, we deal with the isolation, structural elucidation, and biological activities of another active chromoprotein, tentatively termed NeoC-1027, that we found during large-scale production. In particular, we report the isolation and structure of two chromophore components, NeoC-1027 chromophore I (Chr-I) and-II, which could be separated from Chr-III and -IV by reversed-phase HPLC of chromophore preparations freshly extracted from the chromoprotein fraction with EtOAc in the dark.

Fermentation was carried out for 96 hours at $27^{\circ} \mathrm{C}$ under aeration of $0.3 \mathrm{v} . \mathrm{v} . /$ minute and agitation at $25 \mathrm{rpm}$ in a $2-\mathrm{kl}$ tank fermentor containing $1-\mathrm{kl}$ of the production medium composed of glycerol $2.0 \%$, dextrin $2.0 \%$, fishmeal (bonito, Wako Pure Chemical) $0.5 \%$, proteose peptone $0.05 \%$ ( $\mathrm{Difco}$ ) ( $\mathrm{pH} 7.0$ before sterilization). The broth filtrate ( 96 liters) obtained after removing the mycelial cake was treated according to the purification procedures for C-1027, as shown in Fig. 2. The antibiotics were recovered by precipitation with ammonium sulfate at $\mathrm{pH} \mathrm{4}$, and purified by the successive steps of salting out with a UF membrane (SEP-3013, Asahi Chemical Co.), and by hydrophobic and ion-exchange column chromatography with Butyl S and DEAE A-50 cellulofine (Seikagaku Inc.), respectively. At the final step, C-1027 was found to be homogeneous upon the highpressure liquid chromatographic (HPLC) analysis on TSK gel Ether-5PW and TSK gel 2000GSW columns (Tosoh Co., Ltd.), as shown in previous reports ${ }^{1,3)}$. However, HPLC analysis of the extract just after fractionating the crude chromoprotein-preparation suggested the presence of another biologically active chromophore separable from its protein moiety, as monitored by typical UV absorption at both 280 and $350 \mathrm{~nm}$ and antibacterial activity against Micrococcus luteus ATCC 9341. Therefore, separation of this new complex from the chromophore/protein complex of C-1027 could be achieved by careful reversed-phase HPLC analysis of each fraction eluted from a hydrophobic TSK gel phenyl-5PW column $(20 \times 5.5 \mathrm{~cm}$, i.d. $)$ with a linear gradient concentration of $1.5 \mathrm{M}\left(\mathrm{NH}_{4}\right)_{2} \mathrm{SO}_{4}$ in $0.1 \mathrm{M}$ phosphate buffer and $0.1 \mathrm{M}$ phosphate buffer $(\mathrm{pH}$ 6.0) for 300 minutes at a flow rate of $8 \mathrm{ml} /$ minute. The respective bio-active fractions containing $\mathrm{C}-1027$ and NeoC-1027 were separately pooled, desalted with a UF membrane, and then lyophilized as chromophore/protein complex to yield $890 \mathrm{mg}$ and $240 \mathrm{mg}$, respectively. Both C-1027 and NeoC-1027 possessed apoprotein with 
Fig. 1. Structure of chromophore components Chr-I and -II of NeoC-1027 and Chr- III and -IV of C-1027.

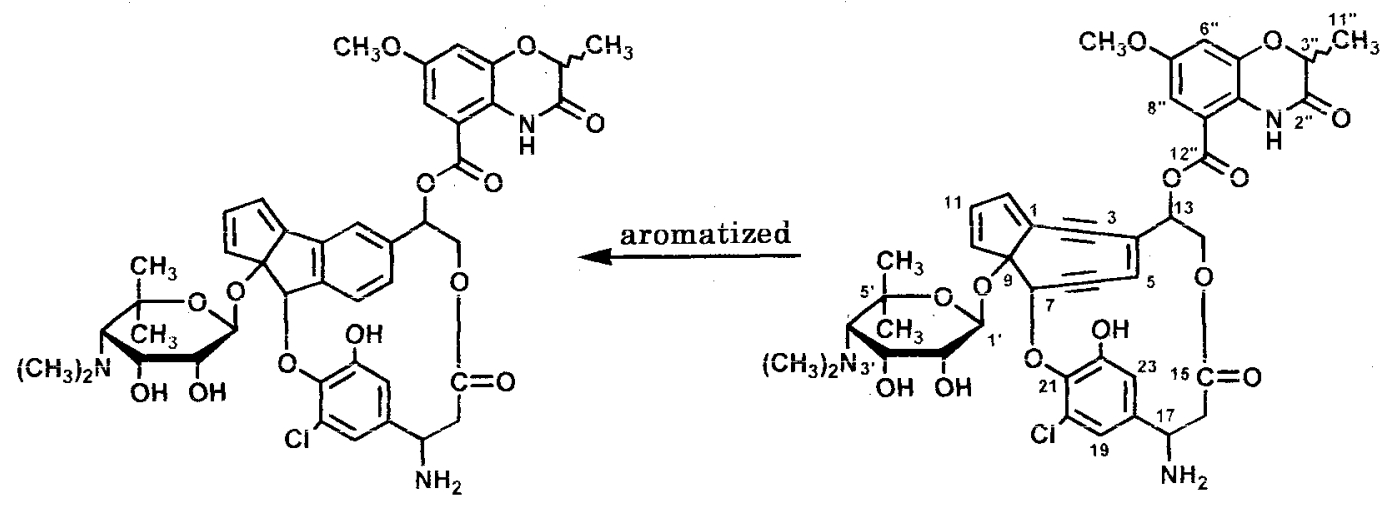

Peak 1 (Chr-I)

Peak 2 (Chr-II)

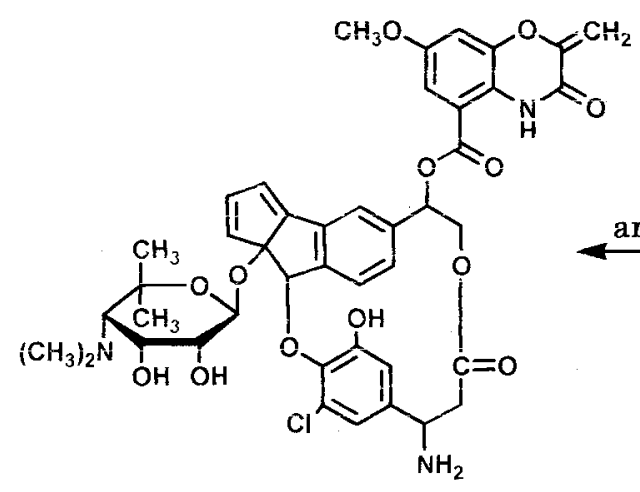

Peak 3 (Chr-III)

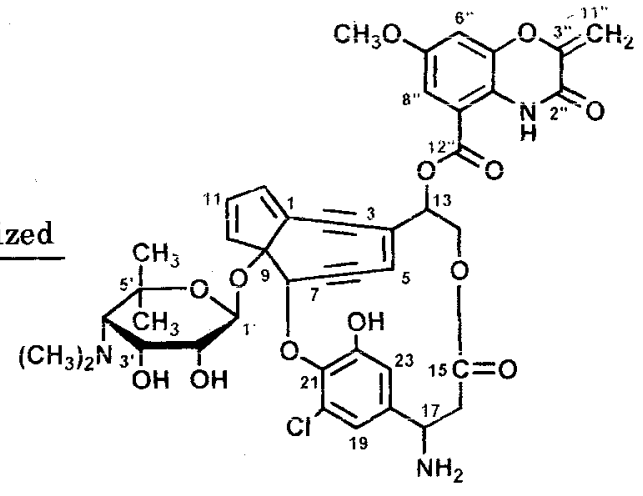

Peak 4 (Chr-IV)

The chromophore components corresponding to peaks 1, 2, 3, and 4 in Fig. 3-a were tentatively named as Chr-I, -II, -III, and -IV, respectively.

similar physico-chemical properties such as amino acid composition, molecular weight and iso-electric point, as described previously for $\mathrm{C}-1027^{3)}$.

As shown in Table 1, both compounds showed similar antibacterial activities with minimum inhibitory concentrations (MICs) of $\leqq 0.05 \sim 0.2 \mu \mathrm{g} / \mathrm{ml}$ against Grampositive bacteria and $0.39 \sim 0.78 \mu \mathrm{g} / \mathrm{ml}$ against some strains of Gram-negative bacteria such as Escherichia coli on Mueller-Hinton agar (Difco) after an 18-hour incubation at $37^{\circ} \mathrm{C}$. NeoC-1027 Chr-I had antibacterial activity with MICs of 100,50 and $100 \mu \mathrm{g} / \mathrm{ml}$, respectively, against Enterococcus faecalis IFO 12968, E. faecium ATCC 6056 and Micrococcus luteus ATCC 9341 among
Gram-positive and -negative bacteria tested. In addition, NeoC-1027 exhibited potent cytotoxic activity against $\mathrm{KB}$ cells even at concentrations less than $0.1 \mathrm{ng} / \mathrm{ml}$, when the $\mathrm{KB}$ cells $\left(2 \times 10^{3}\right.$ cells $\left./ \mathrm{ml}\right)$ were exposed to the antibiotic for 3 days at $37^{\circ} \mathrm{C}$ in Eagle's minimal essential medium supplemented with $10 \%$ fetal calf serum. However, Chr-I of NeoC-1027 did not show cytotoxicity even at the concentration of $10 \mu \mathrm{g} / \mathrm{ml}$. The in vivo antitumor effect of NeoC-1027 was examined by intravenous administration on day $1,5,9$ to male $\mathrm{CDF}_{1}$ mice (6 weeks old) subcutaneously implanted with Colon 26 adenocarinoma fragments $\left(2 \times 2 \times 2 \mathrm{~cm}^{3}\right)$. NeoC- 1027 showed a significant inhibition of tumor growth (74\%) 
Fig. 2. Procedure for purification of antibiotic C-1027 and NeoC-1027 in large-scale production.

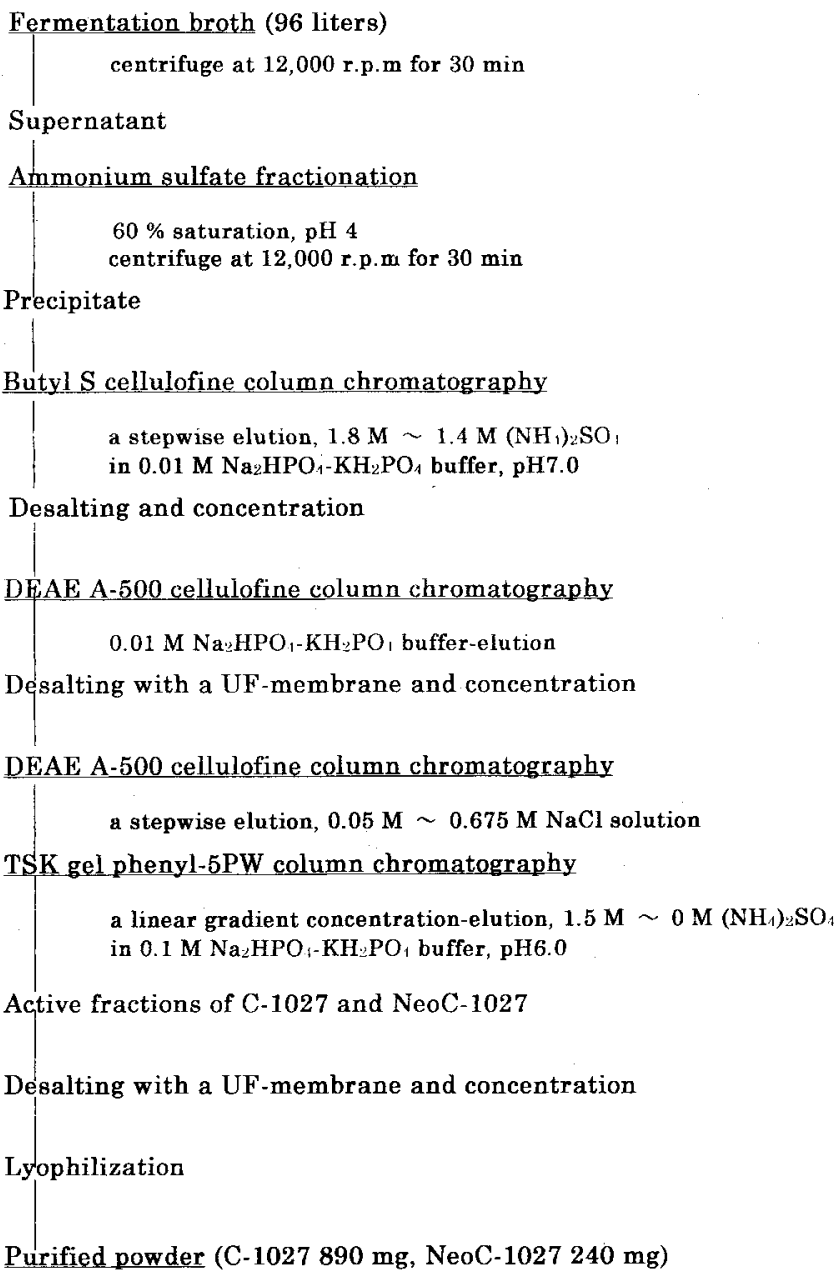

at a dose of $0.05 \mathrm{mg} / \mathrm{kg} /$ day on day 12 (mortality: 0/6).

A typical chromatogram from the reversed-phase HPLC of the chromophore extract from the chromoprotein fraction is shown in Fig 3-a. The four main peaks were tentatively named as Chr-I, -II, -III, and -IV on the basis of their respective order of elution. As shown in preceding communications ${ }^{7 \sim 9)}$, we deduced the structure of C-1027 Chr-IV from the cycloaromatization mechanism leading to the more stable reaction product C-1027 Chr-III. Therefore, the time course of degradation of NeoC-1027 Chr-II in several organic solvents was examined at the room temperature by means of sequential HPLC analysis. As judged by the rate of appearance of degradation product in organic solvent, Chr-II was effectively converted into Chr-I in EtOH (Fig. 3-b), as
Table 1. Antimicrobial spectrum of C-1027 and NeoC-1027.

\begin{tabular}{|c|c|c|}
\hline \multirow{2}{*}{ Test organism } & \multicolumn{2}{|c|}{$\operatorname{MIC}(\mu \mathrm{g} / \mathrm{ml})$} \\
\hline & C-1027 & Neo C-1027 \\
\hline $\begin{array}{l}\text { Staphylococcus aureus } \\
\text { FDA 209P }\end{array}$ & $\leqq 0.05$ & 0.1 \\
\hline S. aureus Terajima & $\leqq 0.05$ & 0.1 \\
\hline S. aureus Smith & $\overline{\leqq} 0.05$ & $\leqq 0.05$ \\
\hline S. epidermidis IFO 3762 & $\leqq 0.05$ & 0.1 \\
\hline $\begin{array}{l}\text { Enterococcus faecium } \\
\text { ATCC } 6056\end{array}$ & $\leqq 0.05$ & $\leqq 0.05$ \\
\hline $\begin{array}{l}\text { Micrococcus luteus } \\
\text { ATCC } 9341\end{array}$ & 0.1 & 0.2 \\
\hline Bacillus subtilis ATCC 6633 & $\leqq 0.05$ & $\leqq 0.05$ \\
\hline B. cereus IFO 3001 & 0.2 & 0.2 \\
\hline B. subtilis $\mathrm{H} 17\left(\mathrm{rec}^{+}\right)$ & $\leqq 0.05$ & 0.1 \\
\hline B. subtilis M45 $\left(\mathrm{rec}^{-}\right)$ & $\leqq 0.05$ & $\leqq 0.05$ \\
\hline Escherichia coli $\mathrm{NIHJ}$ & 50 & $>50$ \\
\hline E. coli $\mathrm{K}-12 \mathrm{C} 600$ & $>50$ & $>50$ \\
\hline E. coli $\mathrm{B}$ & 0.39 & 0.78 \\
\hline E. coli ATCC $27166(\mathrm{NIH})$ & 0.39 & 0.78 \\
\hline $\begin{array}{l}\text { Klebsiella pneumoniae } \\
\text { ATCC } 29665\end{array}$ & $>50$ & $>50$ \\
\hline Proteus vulgaris IID OX -19 & $>50$ & $>50$ \\
\hline Salmonella typhimurium G-46 & $>50$ & $>50$ \\
\hline $\begin{array}{l}\text { Serratia marcescens } \\
\quad \text { IFO } 12648\end{array}$ & $>50$ & $>50$ \\
\hline $\begin{array}{l}\text { Enterobacter cloacae } \\
\text { IFO } 13535\end{array}$ & $>50$ & $>50$ \\
\hline $\begin{array}{l}\text { Pseudomonas aeruginosa } \\
\text { IFO } 13275\end{array}$ & $>50$ & $>50$ \\
\hline
\end{tabular}

The minimum inhibitory concentration (MIC) was determined by the serial agar dilution method using Mueller-Hinton agar at an inoculum size of $10^{6}$ cells $/ \mathrm{ml}$ and a 18 -hour incubation at $37^{\circ} \mathrm{C}$.

seen in the relationship between Chr-III and -IV of $\mathrm{C}-1027^{91}$. Accordingly, the present studies to elucidate the structure of the active component NeoC-1027 Chr-II were performed with the more stable reaction product, NeoC-1027 Chr-I, since Chr-II is highly unstable and undergoes cycloaromatization. The crude chromophore fraction prepared by an EtOAc extraction of proteinprecipitate $(20 \mathrm{~g})$ at alkaline $\mathrm{pH}$ was added to $\mathrm{EtOH}$ and then subjected by preparative HPLC on Inertsil ODS-2 column $(250 \times 20 \mathrm{~mm}$, i.d. $)$ with $\mathrm{CH}_{3} \mathrm{CN} / 0.01 \mathrm{~N}-\mathrm{HCl}$ $(30: 70)$ as a mobile phase with detection of UV-350 nm at flow rate of $8 \mathrm{ml} /$ minute. After removal of $\mathrm{CH}_{3} \mathrm{CN}$, the eluted fraction was lyophilized to obtain the purified Chr-I as its $\mathrm{HCl}$ salt $(1 \mathrm{mg})$. It gave a single peak under the analytical HPLC conditions given in the legend in 
Fig. 3-a. Typical chromatogram from the reversed-phase HPLC of chromophore components.

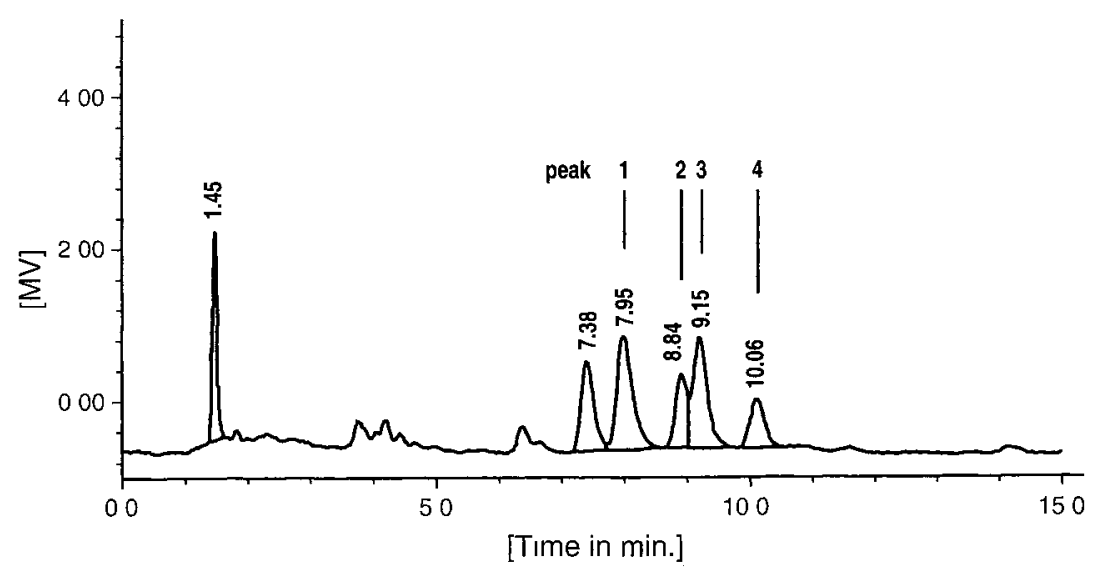

The sample was prepared as an EtOAc extract, after the precipitate, obtained by treatment of the broth filtrate with ammonium sulfate, was dissolved in $0.1 \mathrm{M} \mathrm{K}_{2} \mathrm{HPO}_{4}$ solution.

HPLC conditions:

Column: Inertsil ODS-2 $(150 \times 4.6 \mathrm{~mm}$, i.d. $)$

Temperature: $40^{\circ} \mathrm{C}$

Mobile phase: $20 \mathrm{~mm}$ phosphate buffer $(\mathrm{pH} 6.86) / \mathrm{CH}_{3} \mathrm{CN}(50: 50)$

Flow rate: $1.0 \mathrm{ml} / \mathrm{minute}$

Detection: UV-350 nm

Apparatus: Tosoh SC-8010 system

Fig. 3-b. Time course of degradation of active peak 2.

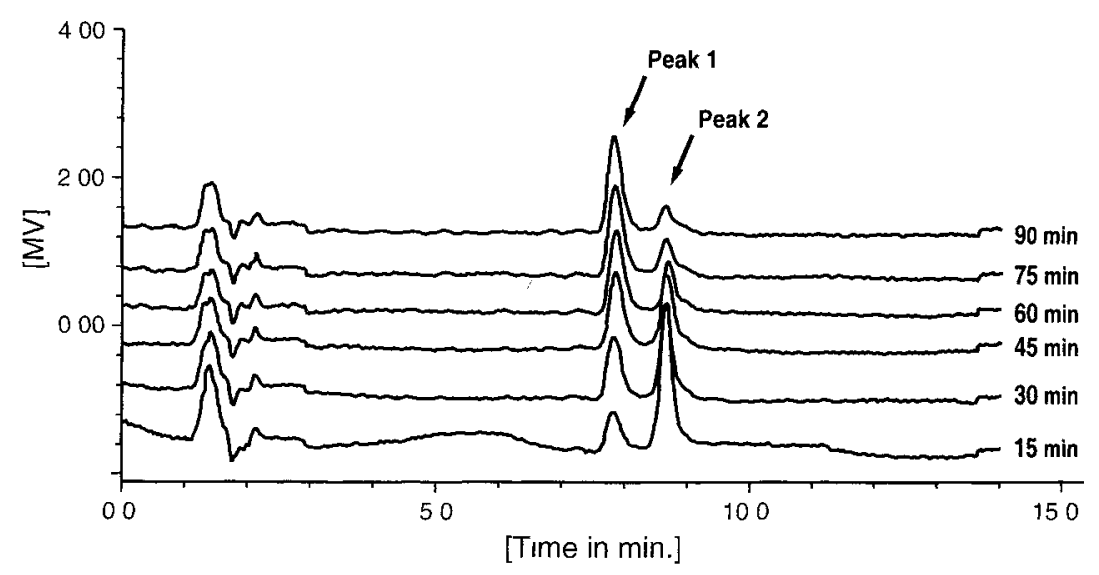

The freshly prepared chromophore fraction Chr-II of NeoC-I027 was added to EtOH and stood at room temperature for the time indicated in the Figure.

HPLC conditions:

Column: Inertsil ODS-2 $(250 \times 20 \mathrm{~mm}, 1 . \mathrm{d}$. $)$

Temperature: room temperature

Mobule phase. $0.01 \mathrm{~N}-\mathrm{HCl} / \mathrm{CH}_{3} \mathrm{CN}(30.70)$

Flow rate: $8.0 \mathrm{ml} /$ minute

Detection: UV-350 nm

Apparatus: Tosoh SC-8010 system 
Table 2. ${ }^{13} \mathrm{C}$ and ${ }^{1} \mathrm{H}-\mathrm{NMR}$ chemical shifts $(\delta, \mathrm{ppm})$ of NeoC-1027 Chr-I in DMSO- $d_{6}$ and $\mathrm{CD}_{3} \mathrm{OD}$.

\begin{tabular}{|c|c|c|c|c|c|c|c|}
\hline \multirow{2}{*}{ Position } & \multicolumn{5}{|c|}{ NeoC-1027 Chr-I (in $\mathrm{CD}_{3} \mathrm{OD}$ ) } & \multicolumn{2}{|c|}{ NeoC-1027 Chr-I (DMSO- $\left.d_{6}\right)$} \\
\hline & $\delta_{\mathrm{C}}(\mathrm{ppm})$ & Multiplicity & $\mathrm{HMBC}^{\mathrm{a}}$ & $\delta_{\mathrm{H}}(\mathrm{ppm})$ & Multiplicity & $\delta_{11}(\mathrm{ppm})$ & Multiplicity \\
\hline 1 & $152.85,152.80$ & $\mathrm{~s}$ & $6.11,(6.69,6.70), 6.76,(7.50)$ & & & & \\
\hline 2 & 137.93 & $s$ & $6.11,(6.69,6.70), 7.44$ & & & & \\
\hline 3 & 118.74 & d & $6.06,6.95$ & $7.56,7.54$ & $1 \mathrm{H}, \mathrm{brs}$ & 7.48 & $\mathrm{lH}, \mathrm{s}$ \\
\hline 4 & 141.36 & $\mathrm{~s}$ & $4.26,6.06,7.44$ & & & & \\
\hline 5 & 127.49 & $\mathrm{~d}$ & $6.06,(7.54,7.56)$ & 6.95 & $1 \mathrm{H}, \mathrm{dd}, 8,1.5 \mathrm{~Hz}$ & 6.87 & $1 \mathrm{H}, \mathrm{dd}, 8,1.5 \mathrm{~Hz}$ \\
\hline 6 & 129.18 & d & & 7.44 & $1 \mathrm{H}, \mathrm{d}, 8 \mathrm{~Hz}$ & 7.24 & $1 \mathrm{H}, \mathrm{d}, 8 \mathrm{~Hz}$ \\
\hline 7 & 148.43 & s & $6.95,(7.54,7.56)$ & & & & \\
\hline 8 & 85.98 & d. & 7.44 & 6.11 & $1 \mathrm{H}, \mathrm{s}$ & 6.02 & $1 \mathrm{H}$, brs \\
\hline 9 & 102.05 & $\mathrm{~s}$ & $4.52,6.11,6.76$ & & & & \\
\hline 10 & 136.99 & $\mathrm{~d}$ & $(6.69,6.70)$ & 6.76 & $1 \mathrm{H}, \mathrm{d}, 1 \mathrm{~Hz}$ & 6.66 & $1 \mathrm{H}, \mathrm{d}, 5 \mathrm{~Hz}$ \\
\hline 11 & 139.08 & $\mathrm{~d}$ & $(6.69,6.70), 6.76$ & 6.76 & $1 \mathrm{H}, \mathrm{d}, \mathrm{IHz}$ & 6.68 & $1 \mathrm{H}, \mathrm{dd}, 5.5,2 \mathrm{~Hz}$ \\
\hline 12 & $128.33,128.30$ & $\mathrm{~d}$ & 6.76 & $6.70,6.69$ & $1 \mathrm{H}$, brs & 6.61 & $1 \mathrm{H}, \mathrm{s}$ \\
\hline 13 & 74.41 & d & $(1.50,1.49)$ & 6.06 & $1 \mathrm{H}, \mathrm{t}, 7.5 \mathrm{~Hz}$ & 5.97 & $1 \mathrm{H}, \mathrm{dd}, 11,5 \mathrm{~Hz}$ \\
\hline 14 & 66.97 & t & 6.06 & 4.26 & $2 \mathrm{H}, \mathrm{d}, 7.5 \mathrm{~Hz}$ & $\begin{array}{l}4.23 \\
4.13\end{array}$ & $\begin{array}{l}1 \mathrm{H}, \mathrm{dd}, 10,5 \mathrm{~Hz} \\
1 \mathrm{H}, \mathrm{dd}, 11,10 \mathrm{~Hz}\end{array}$ \\
\hline 15 & 169.29 & s & $2.59,4.26,4.40$ & & & & \\
\hline 16 & 42.51 & $\mathrm{t}$ & 4.40 & $\begin{array}{l}3.05 \\
2.59\end{array}$ & $\begin{array}{l}1 \mathrm{H}, \mathrm{dd}, 12,3 \mathrm{~Hz} \\
1 \mathrm{H}, \mathrm{t}, 12 \mathrm{~Hz}\end{array}$ & $\begin{array}{l}3.02 \\
2.39\end{array}$ & $\begin{array}{l}1 \mathrm{H}, \mathrm{dd}, 13,2 \mathrm{~Hz} \\
1 \mathrm{H}, \mathrm{t}, 13 \mathrm{~Hz}\end{array}$ \\
\hline 17 & 52.95 & d & $2.59,6.15,6.94$ & 4.40 & $1 \mathrm{H}, \mathrm{dd}, 12,3 \mathrm{~Hz}$ & 4.23 & 1H, overlapped \\
\hline $\mathrm{NH}_{3}-17$ & & & & & & 8.63 & $3 \mathrm{H}$, brs \\
\hline 18 & 134.50 & s & $2.59,4.40$ & & & & \\
\hline 19 & 116.50 & d & $4.40,6.15$ & 6.94 & $1 \mathrm{H}, \mathrm{d}, 2 \mathrm{~Hz}$ & 6.97 & $1 \mathrm{H}, \mathrm{s}$ \\
\hline 20 & 131.48 & s & $6.15,6.94$ & & & & \\
\hline 21 & 141.91 & s & $6.15,6.94$ & & & & \\
\hline 22 & 153.15 & s & 6.15 & & & & \\
\hline $\mathrm{OH}-22$ & & & & & & 8.19 & $1 \mathrm{H}$, brs \\
\hline 23 & 115.36 & $d$ & $4.40,6.94$ & 6.15 & $1 \mathrm{H}, \mathrm{d}, 2 \mathrm{~Hz}$ & 6.04 & $1 \mathrm{H}, \mathrm{d}, 2 \mathrm{~Hz}$ \\
\hline $\mathrm{l}^{\prime}$ & 93.84 & $\mathrm{~d}$ & $3.11,4.25$ & 4.52 & $1 \mathrm{H}, \mathrm{d}, 8 \mathrm{~Hz}$ & 4.53 & $1 \mathrm{H}$. brs, $7 \mathrm{~Hz}$ \\
\hline $2^{\prime}$ & 71.17 & d & 4.25 & 3.11 & $1 \mathrm{H}, \mathrm{dd}, 8,3.5 \mathrm{~Hz}$ & 2.93 & 1H. brs \\
\hline $\mathrm{OH}-2^{\prime}$ & & & & & & & \\
\hline $3^{\prime}$ & 68.73 & $\mathrm{~d}$ & & 4.25 & $1 \mathrm{H}$, overlapped & 4.07 & $\mathrm{lH}, \mathrm{brs}$ \\
\hline $\mathrm{OH}-3^{\prime}$ & & & & & & & \\
\hline $4^{\prime}$ & 71.96 & d & $1.53,2.98,4.25$ & 3.18 & $1 \mathrm{H}, \mathrm{d}, 3 \mathrm{~Hz}$ & 3.10 & $1 \mathrm{H}, \mathrm{brs}$ \\
\hline $\mathrm{N}\left(\mathrm{CH}_{3}\right)_{2}-4^{\prime}$ & 44.90 & $q$ & $2.98,3.18$ & 2.98 & $6 \mathrm{H}, \mathrm{s}$ & 2.83 & $6 \mathrm{H}$, br s \\
\hline $\mathrm{NH}-4^{\prime}$ & & & & & & 9.05 & $1 \mathrm{H}, \mathrm{brs}$ \\
\hline $5^{\prime}$ & 76.61 & s & $1.53,3.18,4.25,4.52$ & & & & \\
\hline $\mathrm{CH}_{3}-6^{\prime} \alpha$ & 32.56 & $q$ & $1.53,3.18$ & 1.53 & $6 \mathrm{H}, \mathrm{s}$ & 1.46 & $3 \mathrm{H}, \mathrm{s}$ \\
\hline $\mathrm{CH}_{3}-\mathrm{C}^{\prime} \beta$ & 21.72 & $\mathrm{q}$ & $1.53,3.18$ & & & 1.44 & $3 \mathrm{H}, \mathrm{s}$ \\
\hline $\mathrm{NH}-1^{\prime \prime}$ & & & & & & 9.82 & $1 \mathrm{H}, \mathrm{s}$ \\
\hline $2^{\prime \prime}$ & 168.69 & s & $(1.50,1.49) ;(4.68,4.67)$ & & & & \\
\hline $3^{\prime \prime}$ & 74.12 & $\mathrm{~d}$ & $4.26,6.95,(7.56,7.54)$ & $4.68,4.67$ & $1 \mathrm{H}, \mathrm{q}, 7 \mathrm{~Hz}$ & 4.79 & $1 \mathrm{H}, \mathrm{q}, 7 \mathrm{~Hz}$ \\
\hline $5^{\prime \prime}$ & 146.19 & s & $(4.68,4.67), 6.90$ & & & & \\
\hline $6^{\prime \prime}$ & 110.21 & $d$ & 7.34 & 6.90 & $1 \mathrm{H}, \mathrm{d}, 3 \mathrm{~Hz}$ & 7.04 & $\mathrm{lH}, \mathrm{d}, 3 \mathrm{~Hz}$ \\
\hline $7^{\prime \prime}$ & 156.75 & s & $3.84,6.90,7.34$ & & & & \\
\hline $\mathrm{OCH}_{3}-7^{\prime \prime}$ & 56.52 & $\mathrm{q}$ & & 3.84 & $3 \mathrm{H}, \mathrm{s}$ & 3.82 & $3 \mathrm{H}, \mathrm{s}$ \\
\hline $8^{\prime \prime}$ & 109.89 & $\mathrm{~d}$ & 6.90 & 7.34 & $1 \mathrm{H}, \mathrm{d}, 3 \mathrm{~Hz}$ & 7.29 & $1 \mathrm{H}, \mathrm{d}, 3 \mathrm{~Hz}$ \\
\hline $9^{\prime \prime}$ & $115.07,115.04$ & s & 7.34 & & & & \\
\hline $10^{\prime \prime}$ & 124.54 & s & $6.90,7.34$ & & & & \\
\hline $\mathrm{CH}_{3}-11^{\prime \prime}$ & $16.50,16.48$ & q & $(4.68,4.67)$ & $1.50,1.49$ & $3 \mathrm{H}, \mathrm{d}, 7 \mathrm{~Hz}$ & 1.42 & $3 \mathrm{H}, \mathrm{d}, 7 \mathrm{~Hz}$ \\
\hline $12^{\prime \prime}$ & 166.48 & s & $6.06,7.34$ & & & & \\
\hline
\end{tabular}

${ }^{13} \mathrm{C}$ and ${ }^{1} \mathrm{H}$ NMR spectra were recorded at $100 \mathrm{MHz}$ and $400 \mathrm{MHz}$, respectively, at $30^{\circ} \mathrm{C}$; Coupling constants are given in $\mathrm{Hz}$.

a Figures in parentheses indicate a pair of signals corresponding to the diastereomers of NeoC-1027 Chr-I. 
Fig. 3-a.

The UV-absorption spectrum of NeoC-1027 ChrI showed close similarity to that of Chr-III around 205, 229 (sh), 278, and $355 \mathrm{~nm}$. FAB-MS spectra at positive mode; $870(\mathrm{M}+\mathrm{Na})^{+}, m / z 848(\mathrm{M}+\mathrm{H})^{+}$and at negative mode; $m / z 846(\mathrm{M}-\mathrm{H})^{-}$of $\mathrm{Chr}-\mathrm{I}$ showed its nominal molecular weight to be 847 . Furthermore, HRFAB-MS [found $m / z 848.2741$, calcd. $m / z 848.2797$ for $\left.\mathrm{C}_{43} \mathrm{H}_{46} \mathrm{~N}_{3} \mathrm{O}_{13} \mathrm{Cl}+\mathrm{H}\right]$ suggested the molecular formula as $\mathrm{C}_{43} \mathrm{H}_{46} \mathrm{~N}_{3} \mathrm{O}_{13} \mathrm{Cl}$. By comparison with the molecular weight of C-1027 Chr-III (MW 845), Chr-I was deduced to be a hydrogenated compound of Chr-III. The ${ }^{1} \mathrm{H}$ and ${ }^{13} \mathrm{C}$ NMR studies of $\mathrm{Chr}-\mathrm{I}$ were performed in both $\mathrm{DMSO}-d_{6}$ and $\mathrm{MeOH}-d_{4}$ solutions at $30^{\circ} \mathrm{C}$, and these results are summarized in Table 2. The ${ }^{1} \mathrm{H}$ NMR spectrum in DMSO- $d_{6}$ solution showed a doublet methyl signal and quartet methine signal at $1.42 \mathrm{ppm}$ and $4.79 \mathrm{ppm}$, respectively. Moreover, exo-methylene signals corresponding to the oxazine side chain of Chr-III were not observed. This indicated that saturation of the exo-methylene group in oxazine side chain of Chr-III has occurred. Based on the ${ }^{1} \mathrm{H}$ NMR spectrum in DMSO- $d_{6}$ solution, Chr-I seemed to be a single component, but some signals split into two peaks, when $\mathrm{MeOH}-d_{4}$ was used as solvent. Further, when the detailed NMR analyses including ${ }^{13} \mathrm{C}$ NMR, HMQC, and $\mathrm{HMBC}$ experiments were performed in $\mathrm{MeOH}-d_{4}$ solution, Chr-I was suspected to be a mixture consisting of two isomers. The signal splitting in the ${ }^{1} \mathrm{H}$ NMR and ${ }^{13} \mathrm{C}$ NMR spectra was quite small except for the proton signals of the doublet methyl (1.50 and $1.49 \mathrm{ppm})$ and quartet methine (4.68 and $4.67 \mathrm{ppm}$ ). Consequently, these components were considered to be stereochemical isomers (diastereomers) at the methyl group in the oxazine side chain; and the respective structures of Chr-I and -II in NeoC-1027 were determined to be those shown in Fig. 1. Taking the relationship between NeoC-1027 Chr-I and Chr-II into consideration, Chr-II should be a corresponding enediyne mother compound, as seen in the relationship between Chr-III and -IV in C-1027.

We and SugIura et al. ${ }^{14,15)}$ reported that analysis of the fluorescence and circular dichroism spectra of C-1027, apoprotein, and chromophore revealed a specific $1: 1$ binding of chromophore to the apoprotein, and significant interaction of the oxazine group with apoprotein in the chromophore/apoprotein complex. Recent studies have showed that removal of the oxazine group in the aromatized form of C-1027 chromophore resulted in a 400 -fold reduction in DNA binding affinity $^{16)}$. Further, NMR experiments and distance- restrained molecular dynamics computations for the complex of the DNA oligomer with the aromatized product Chr-III have indicated intercalative and minor-groove binding of the oxazine and amino sugar moieties, respectively ${ }^{17}$. Thus, observations of DNA intercalation by the oxazine moiety of $\mathrm{C}-1027$ suggest the conservation of a unique class of DNA-binding elements, as also occurs with the anthranilate of esperamicin $A_{1}{ }^{18)}$. The difference in the structures of Chr-II and Chr-IV might provide us a clue as to the participation of the tertiary structure of the apoprotein in the chromophore binding and the detailed elucidation for function of oxazine side chain in chromophore in an intercalative DNA binding mode in $\mathrm{C}-1027$ antibiotic. In practice, separation of $\mathrm{C}-1027$ and Neo-C-1027 may be achieved by taking advantage of the slight difference in the structure of their Chr-II and IV in the purification of these compounds on a hydrophobic column of TSK gel phenyl-5PW (Tosoh Co., Ltd.).

\section{Acknowledgments}

The authors are indebted to Dr. NORIO UNEMI, Director of our laboratory, and to Dr. WU JIAN-PO, Director of the Institute of Medicinal Biotechnology in The People's Republic of China, for their valuable comments and suggestions during the course of this study.

\section{References}

1) Otani, T.; Y. Minami, T. Marunaka, R. Zhang \& M.-Y. XIE: A new macromolecular antitumor antibiotic, C-1027. II. Isolation and physico-chemical properties. J. Antibiotics 41: 1580 1585, 1988

2) Zhen, Y.-S.; X.-Y. Ming, B. Yu, T. Otani, H. Saito \& Y. YAMADA: A new macromolecular antitumor antibiotic, C-1027. III. Antitumor activity. J. Antibiotics 42: 1294 1298, 1989

3) Otani, T.; T. Yasuhara, Y. Minami, T. Shimazu, R. ZHANG \& M.-Y. XIE: Purification and primary structure of C-1027-AG, a selective antagonist of antitumor antibiotic C-1027, from Streptomyces globisporus. Agric. Biol. Chem. 55: 407 417, 1991

4) Sakata, N.; S. Ikeno, M. Hori, M. Hamada \& T. OTANI: Cloning and nucleotide sequencing of the antitumor antibiotic C-1027 apoprotein gene. Biosci. Biotech. Biochem. 56: 1592 1595, 1992

5) Smith, A. L. \& K. C. Nicolaou: The enediyne antibiotics. J. Med. Chem. 39: $2103 \sim 2117,1996$

6) MAEDA, H.; K. Edo \& N. IsHidA (Eds.): Neocarzinostatin, The past, present, and future of an anticancer drug. Springer-Verlag, Tokyo, 1997

7) Minami, Y.; K.-I. Yoshida, R. Azuma, M. Saeki \& T. OTANI: Structure of an aromatization product of C-1027 chromophore. Tetrahedron Letters 34: 2633 2636, 1993

8) Yoshida, K.-I.; Y. Minami, R. Azuma, M. Saeki \& 
T. OTANI: Structure and cycloaromatization of a novel enediyne, C-1027 chromophore. Tetrahedron Letters 34: $2637 \sim 2640,1993$

9) Yoshida, K.-I.; Y. Minami, T. Otani, Y. Tada \& M. Hirama: Remarkable kinetic solvent isotopic effect on the cycloaromatization of C-1027 chromophore, a 9-membered enediyne, and thermochemistry. Tetrahedron Letters 35: 5253 5256, 1994

10) Suglura, Y. \& T. Matsumoto: Some characteristics of DNA strand scission by macromolecular antitumor antibiotic C-1027 containing a novel enediyne chromophore. Biochemistry 32: 5548 5553, 1993

11) Cobuzzi, R. J.; S. K. Kotsopoulos, T. Otani \& T. A. BEERMAN: Effects of the enediyne C-1027 on intercellular DNA targets: Biochemistry 34: $583 \sim 592$, 1995

12) Xu, Y.-J.; Y.-S. Zhen \& I. H. GolgberG: C-1027 chromophore, a potent new enediyne antitumor antibiotic, induces sequence-specific double-strand DNA cleavage. Biochemistry 33: 5947 5954, 1994

13) Sakata, N.; K. S-Tsuchiya, Y. Moriya, H. Hayashi, M. Hori, T. Otani, M. Nagal \& T. Aoyagi: Aminopeptidase activity of an antitumor antibiotic, C-1027. J. Antibiotics 45: I13 117, 1992
14) Otani, T.: Conformation studies on and assessment by spectral analysis of the protein-chromophore interaction of the macromolecular antitumor antibiotic C-1027. J. Antibiotics 46: 791 802, 1993

15) Matsumoto, T.; Y. Okuno \& Y. Sugiura: Specific interaction between a novel enediyne chromophore and apoprotein in macromolecular antitumor antibiotic C-1027. Biochem. Biophys. Res. Commn. 195: $659 \sim 666,1993$

16) Yu, L.; S. Mah, T. Otani \& P. Dedon: The benzoxazolinate of $\mathrm{C}-1027$ confers intercalative DNA binding. J. Am. Chem. Soc. 117: 8877 8878, 1995

17) Okuno, Y.; T. Imashita, T. Otani \& Y. Sugiura: Interaction of C-1027 chromophore with $d$ (GTATAC $)_{2}$ : A binding model based on NMR experiments. J. Am. Chem. Soc. 118: 4729 47301996

18) YU, L.; J. GoliK, R. Harrison \& P. Dedon: The deoxyfucose-anthranilate of esperamicin Al confers intercalative DNA binding and causes a switch in the chemistry of bistranded DNA lesions: J. Am. Chem. Soc. 116: 9733 9738, 1994 